\title{
Prediction Of CUTTING ForCes IN THE DRY MACHINING OF Lights AlLOYS
}

\author{
Domingo, R.; Alvarez, R. \& SEbastian, M. A.
}

Abstract: This paper analyses the relationship between the cutting forces and length, according to experimental results obtained in lights alloys, in particular UNS A97050-T7, UNS A92024-T3, during the dry drilling. The tests have been performed with several cutting speed, $83 \mathrm{~m} / \mathrm{min}, 60 \mathrm{~m} / \mathrm{min}$ and $50 \mathrm{~m} / \mathrm{min}$. Box-Cox transformations have allowed finding a fitted model and determining a significant relationship between maximum cutting forces, for each hole, and cutting length. Thus, it is possible to establish prediction limits for new observations of cutting forces, at 95\% confidence level.

Key words: Box-Cox transformations, cutting forces, machining
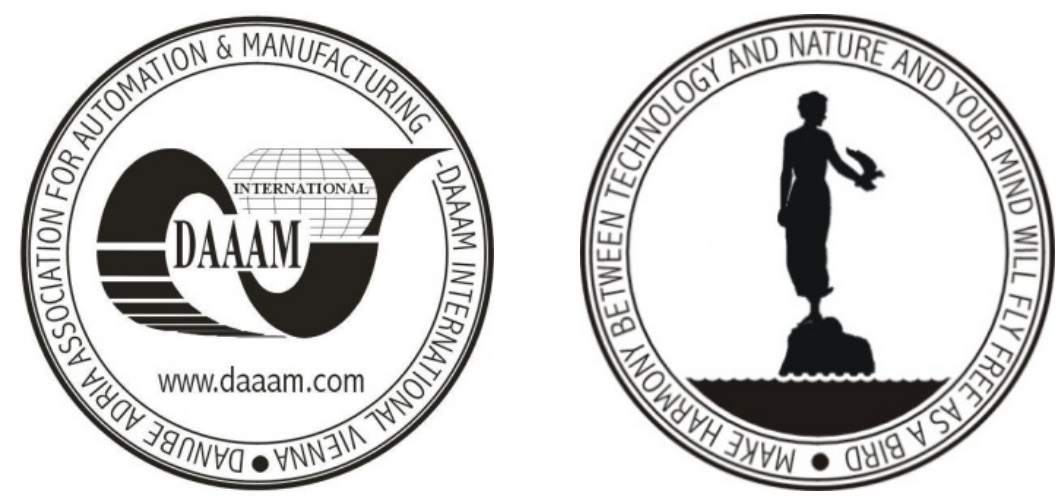

Authors' data: Prof.Dr.Eng. Domingo, R[osario]*; Prof.Dr.Eng. Álvarez, R[oberto]**; Prof.Dr.Eng Sebastián, M[iguel] A[ngel]*, *Department of Manufacturing Engineering, National Distance University of Spain (UNED), C/ Juan del Rosal 12 (Ciudad Universitaria), 28040 Madrid, Spain, **Nebrija University, C/ Pirineos 55, 28040 Madrid, Spain, rdomingo@ind.uned.es, ralvarez@nebrija.es, msebastian@ind.uned.es

This Publication has to be referred as: Domingo, R[osario]; Álvarez, R[oberto] \& Sebastián, M[iguel] A[ngel] (2009). Prediction of Cutting Forces in the Dry Machining of Lights Alloys, Chapter 78 in DAAAM International Scientific Book 2009, pp. 815-822, B. Katalinic (Ed.), Published by DAAAM International, ISBN 978-3-901509-69-8, ISSN 1726-9687, Vienna, Austria

DOI: 10.2507/daaam.scibook.2009.78 